\begin{tabular}{|c|c|c|}
\hline Divrei HaKnesset & 一 & Records of Knesset proceedings \\
\hline HaPraklif & 一 & $\begin{array}{l}\text { Law Journal published by the Jewish Bar } \\
\text { Association (1943-48), now the Israel Bar, } \\
\text { and, since 1964, in cooperation with the } \\
\text { Faculty of Law of the Hebrew University, } \\
\text { Jerusalem }\end{array}$ \\
\hline Hatza' of Hok & - & Legislative Bills \\
\hline Iton Rishmi & $\longrightarrow$ & $\begin{array}{l}\text { The Official Gazette during the tenure of } \\
\text { the Provisional Council of State }\end{array}$ \\
\hline Kitvei Amana & $\longrightarrow$ & Israel Treały Documents \\
\hline Knesset & 一 & Israel Legislative Assembly \\
\hline Kovetz HaTakanof & - & Subsidiary Legislation \\
\hline Piskei Din (Judgments) & - & $\begin{array}{l}\text { Law reports of the Supreme Court, pub- } \\
\text { lished by the Ministry of Justice }(1948-1\end{array}$ \\
\hline Psakim (Decisions) & - & $\begin{array}{l}\text { Law reports of the Supreme Court and } \\
\text { District Courts, published privately (1948) }\end{array}$ \\
\hline $\begin{array}{l}\text { Psakim 'Elyon } \\
\text { (Supreme [Court] Decisions) }\end{array}$ & - & $\begin{array}{l}\text { Law reports of the Supreme Court, pub- } \\
\text { lished by the Israel Bar Association (1948- } \\
1961)\end{array}$ \\
\hline $\begin{array}{l}\text { Psakim Mehoziim } \\
\text { (District [Courts] Decisions) }\end{array}$ & - & $\begin{array}{l}\text { Law reports of the District Courts, pub- } \\
\text { lished by the Israel Bar (1949-) }\end{array}$ \\
\hline Reshumot & 一 & Official Gazette \\
\hline Sefer HaHukim & 一 & Principal Legislation \\
\hline Yalkut HaPirsumim & - & Government Notices \\
\hline
\end{tabular}

- Records of Knesset proceedings

Law Journal published by the Jewish Bar Association (1943-48), now the Israel Bar, and, since 1964, in cooperation with the Faculty of Law of the Hebrew University, Jerusalem

- Legislative Bills the Provisional Council of State

- Israel Treaty Documents

Law reports of the Supreme Court, pubLaw reports of the Supreme Court and published privately (1948) lished by the Israel Bar Association (1948-

Law reports of the District Courts, pub-

Official Gazette

- Government Notices

\title{
ABBREVIATIONS
}

A.L.R. - Annotated Law Reports (1943-47)

F.H. - Further Hearings

K.A. - Kitvei Amana (in Hebrew)

K.T. - Kovełz HaTakanot (in Hebrew)

L.S.I. - Laws of the State of Israel

P.D. - Piskei Din (in Hebrew)

P.E. - Psakim 'Elyon (in Hebrew)

P.L.R. - Palestine Law Reports, 1920-47

P.M. - Psakim Mehoziim (in Hebrew)

P.M.S. - Psakim Mehoziim Summary (in Hebrew)

P.G. - Palestine Gazette

Rot. - Rottenberg's Law Reports (1919-36)

S.C.J. - Annotated Supreme Court Judgments (1937-42)

S.D.C. - Selected Cases of the District Court (1943-47)

S.J. - Selected Judgments of the Supreme Court of Israel (1948-58) 
The Israel Law Review appears four times a year (ca. 600 pp.).

Annual Subscription Rates:
Israel
IL 22
United Kingdom
\& 3
U.S.A. and other countries $\$ 10$ or the equivalent
(Post Free)

\section{Single Copies:}
Isroel
IL 6
United Kingdom
175
U.S.A. and other countries $\$ 2.80$ or the equivalent

\section{THE ISRAEL LAW REVIEW ASSOCIATION}

c/o Foculty of Law, Hebrew University of Jerusalem 